\title{
New records of the restinga antwren Formicivora littoralis Gonzaga and Pacheco (Aves, Thamnophilidae) in the state of Rio de Janeiro, Brazil: inland extended range and threats
}

\author{
Vecchi, MB. ${ }^{\mathrm{a}}$ and Alves, MAS. ${ }^{\mathrm{b} *}$ \\ aPrograma de Pós-Graduação em Biologia, Universidade do Estado do Rio de Janeiro - UERJ, \\ Rua São Francisco Xavier, 524, CEP 20550-011, Rio de Janeiro, RJ, Brazil \\ bDepartamento de Ecologia, Universidade do Estado do Rio de Janeiro - UERJ, \\ Rua São Francisco Xavier, 524, CEP 20550-011, Rio de Janeiro, RJ, Brazil \\ *e-mail: masaal@globo.com
}

Received June 19, 2006 - Accepted February 28, 2007 - Distributed May 31, 2008

(With 1 figure)

\begin{abstract}
The Restinga Antwren (Formicivora littoralis) has a narrow distribution range in southeastern Brazil, and it is a typical species of restinga habitat (sandy coastal plain vegetation). In this paper, we describe two new records for the species ( $22^{\circ} 51^{\prime} 45^{\prime \prime} \mathrm{S}$ and $42^{\circ} 14^{\prime} 13^{\prime \prime} \mathrm{W} ; 22^{\circ} 51^{\prime} 14^{\prime \prime} \mathrm{S}$ and $\left.42^{\circ} 11^{\prime} 47^{\prime \prime} \mathrm{W}\right)$ in the northern margin of the Araruama Lagoon, which represent a new inland limit for its distribution $(11 \mathrm{~km})$, besides assessing the current state of its habitat. We recorded supposed isolated subpopulations, most of them due the accelerated human-made fragmentation. The Massambaba Environmental Protection Area comprises the larger continuous extent of the suitable habitat for the Restinga Antwren, being essential to its long-term existence. However, the region lacks effective protected areas and, besides urgent practical measures, we recommend an accurate mapping and populational studies on this species.
\end{abstract}

Keywords: Atlantic forest, conservation, distribution, Restinga Antwren, southeastern Brazil.

\section{Novos registros do Formigueiro-do-litoral, Formicivora littoralis Gonzaga e Pacheco (Aves: Thamnophilidae) no Estado do Rio de Janeiro, Brasil: expansão da distribuição continental e ameaças}

\begin{abstract}
Resumo
Formicivora littoralis tem uma restrita faixa de distribuição no Sudeste do Brasil, sendo uma espécie típica de restinga. Descrevemos dois novos registros para a espécie (22 51'45" S e 42 14 ' 13" W; 22 51' 14" S e 42 $11^{\circ}$ ' 47" W) na margem norte da Lagoa de Araruama, que representam um novo limite continental para sua distribuição (11 km), além de avaliar o atual estado de seu habitat. Registramos subpopulações supostamente isoladas, a maioria devido ao acelerado processo de fragmentação por intervenção antrópica. A Área de Proteção Ambiental de Massambaba compreende a maior extensão de habitat adequado para $F$. littoralis, essencial para sua existência a longo prazo. No entanto, a região carece de áreas de proteção efetiva. Recomendamos medidas práticas urgentes, além de um mapeamento acurado e estudos populacionais sobre essa espécie.
\end{abstract}

Palavras-chave: Mata Atlântica, conservação, distribuição, Formicivora littoralis, sudeste do Brasil.

\section{Introduction}

The Restinga Antwren Formicivora littoralis is considered the only bird species endemic of restinga habitats, which are sandy coastal plain vegetation associated to the Atlantic forest. It was first described as a subspecies of Serrana Antwren F. serrana (Gonzaga and Pacheco, 1990), and considered later as a separate species (Collar et al., 1992; Ridgely and Tudor, 1994), based on morphological and ecological differences (Collar et al., 1992). The species' biology is still little known, and due to the continuous and accelerated loss of its highly re- strict habitat, it is currently categorized as critically endangered (IUCN, 2004). It is known only for the state of Rio de Janeiro, southeastern Brazil, in the municipalities of Cabo Frio, São Pedro da Aldeia, Arraial do Cabo, Araruama (Praia Seca district) and Saquarema (Gonzaga and Pacheco, 1990).

In the present study we recorded two new localities for the species in the state of Rio de Janeiro, both in the municipality of Iguaba Grande, occurring in small patches of restinga in the northern margin of Araruama 
Lagoon. Additionally, we assessed the current conditions and requirements for conservation of the restinga remnants along the area of known distribution for this species.

\section{Material and Methods}

We started collecting data in August 2003, during a study on the avifauna in the municipality of Iguaba Grande. Along 2004 and 2005, we checked all the northern margin of the Araruama Lagoon, in order to detect remnants of restinga vegetation and possible new sites with the Restinga Antwren. In addition, we revisited all the range of its distribution to assess current geographical limits and the conservation status of its habitat. In each sampled area, we used the technique of playback, playing the species' vocalization previously recorded.

This technique is especially recommended for secretive species and dense habitats (Johnson et al., 1981), which is the case for the studied species. In order to document the presence or absence of the Restinga Antwren in each sampled site, we played the tape for c. 5 minutes in one or more vegetated points, avoiding the hottest period of the day (11-15 hours). Although restinga seems a relatively open habitat, it is composed by patches of vegetation nearly impenetrable, which makes it hard to detect the Restinga Antwren visually without playback. Both sexes respond very well to playback and apparently all long throughout the year (pers. obs.).

\section{Results}

The first new record of the Restinga Antwren occurred in August 2003 by one of the authors (MBV), in a restinga area in Morro do Governo, in between the mu- nicipalities of Iguaba Grande and São Pedro da Aldeia. The second new record was in a small fragment in Ponta das Andorinhas, western Iguaba Grande. The two sites lie among urban beaches, in a highly disturbed region (Figure 1).

Morro do Governo (22 $51^{\prime} 14^{\prime \prime} \mathrm{S}$ and $42^{\circ} 11^{\prime}$ 47' $\mathrm{W}$ ) comprises a patch between a state road (RJ 106) and the Araruama Lagoon, $11 \mathrm{~km}$ far from the seashore, with approximately 80 ha of well preserved vegetation. Decades ago, before the construction of a railway and, subsequently, of roads and streets, this area was connected with the Serra de Sapiatiba, currently the main Atlantic forest remnant (> 300 ha) in the surroundings. The site is a university campus and, despite the presence of restinga habitat near the beach, most of the area is covered by seasonally dry forest, a typical physiognomy of that region, which highest hills locally reaching c. $60 \mathrm{~m}$. In Morro do Governo, the Restinga Antwren apparently occupies only restinga vegetation up to a few dozen meters far from the lagoon. During a study on the local avifauna carried out from January to July 2004, no individual has been observed or mist-netted in the forest area. On the other hand, in the restinga area the Restinga Antwren was the fifth most well-sampled bird among a total of 33 mist-netted species (Vecchi et al., unplub. data). Besides Ponta das Andorinhas, the only other place bordering the northern of Araruama Lagoon where the species is known to occur is Ponta dos Cardeiros (Gonzaga and Pacheco, 1990), $7 \mathrm{~km}$ to the east.

Some hectares of restinga considerably disturbed remain at the margins of Araruama Lagoon in Ponta das Andorinhas. We only saw the Restinga Antwren twice in a privately owned area enclosed with a wood and wire fence (Sítio das Andorinhas, $22^{\circ} 51$ ' 45" S and

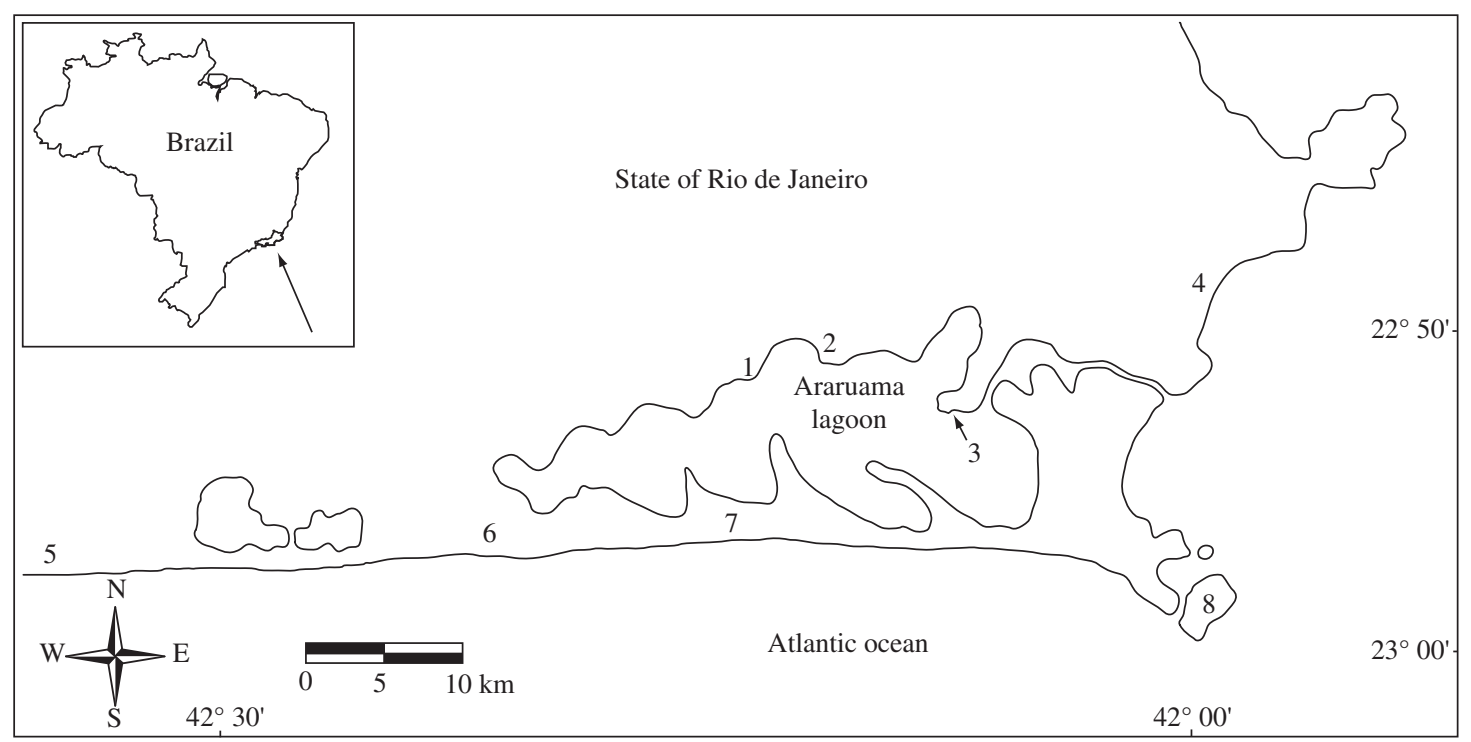

Figure 1. Some recorded localities of the Restinga Antwren in the state of Rio de Janeiro, southeastern Brazil: 1) Ponta das Andorinhas (new record), 2) Morro do Governo (new record), 3) Ponta dos Cardeiros, 4) Praia do Peró, 5) Jaconé, 6) Praia do Dentinho, 7) Praia de Massambaba, and 8) Ilha de Cabo Frio. 
$42^{\circ} 14$ ' 13 " W). On both occasions we used the playback (September 2004, December 2005) to attract the species and only one pair of birds was seen approximately $10 \mathrm{~m}$ far from the lagoon, in dense restinga vegetation. We did not enter the property; therefore we do not know how far from the beach these birds could be found there. However, the inland limit of the property lies c. $600 \mathrm{~m}$ far from the lagoon margin, and most of it is vegetated.

\subsection{Present distribution}

Based on our data, the extremes of distribution of the Restinga Antwren comprise, considering a straight line, less than $70 \mathrm{~km}$. The northern limit that we recorded for the species during the present study was the central portion of Praia do Peró ( $22^{\circ} 50^{\prime} 07^{\prime}$ ' S). This beach as a whole can be characterized by low shrubby open restinga, becoming lower and sparser towards the north. The northern limit of our search was the final portion of this beach (Pontal do Peró), where the restinga becomes dense and compact, and where the species was not recorded.

In the district of Jaconé (Saquarema), the western extreme of distribution of the Restinga Antwren, it has been recorded in a $30 \times 160 \mathrm{~m}$ fragment $\left(42^{\circ} 37^{\prime} 48^{\prime \prime} \mathrm{W}\right)$ surrounded by houses. The next nearest fragment in which we found the Restinga Antwren lies $3 \mathrm{~km}$ to the east. In all the sampled coastal range, this district represents the most disturbed area, where there is no expressive area legally protected occupied by the Restinga Antwren. Due to human occupation and its high-impact actions in this area, we found the species only in small fragments of land, many of them being plots for sale. We did not find any evident geographic or ecological constraint for the species' distribution beyond its north and west limits.

Towards the east from Jaconé, the first extensive patch in which we recorded the species was the first portion of the Massambaba Environmental Protection Area (APA Massambaba), in the Jacarepiá restinga, $18 \mathrm{~km}$ far from the western limit for the species. Despite the fact that this site comprises a $3 \mathrm{~km}$ strip along the coast with well-preserved restinga (up to the district of Vilatur), the Restinga Antwren occupies only a $0.9 \mathrm{~km}$ range of restinga near the beach line, being absent from the remaining extension, where the sand is almost exclusively occupied by the dwarf sand palm (Alagoptera arenaria (Gomes) O. Kuntze). There is a narrow strip of tall arboreal restinga in the second and inner sandy ridge, about $0.5 \mathrm{~km}$ far from the coast, where we did not record the species, despite the little disturbance in the area. In the region between the Araruama Lagoon and the Atlantic Ocean, eastwards from Praia do Dentinho, district of Praia Seca (Araruama), the species can be more frequently found.

Although we investigated all the northern part of the Araruama lagoon, including approximately $2 \mathrm{~km}$ from the lagoon to the interior, we did not find the Restinga Antwren in any other fragment besides the two new record sites. Similar to these new record sites, most of the sampled region is very fragmented, as a consequence of the human occupation and infrastructure develop- ment. Nevertheless, the suitable habitat coverage for the Restinga Antwren has several naturally discontinuous patches, showing kilometers-wide lacunas, such as bare sand extensions, areas covered by herbaceous vegetation and swamps, apparently with no relationship to humanmade disturbance.

\section{Discussion}

Our new records of the Restinga Antwren, c. $11 \mathrm{~km}$ far from the shore, represent a new inland limit for the species. Nevertheless, these areas suffer high influence from the sea, and the recorded individuals were always near the margin of the Araruama Lagoon, a highly saline environment. Concerning the distribution range of the Restinga Antwren, little is increased by our particular data, but the presence of these relict subpopulations in the middle of the northern margin of the Araruama Lagoon suggests the original distribution of this species comprised the restingas around the whole perimeter of the lagoon. The subsequent habitat destruction due to human activities would have confined its distribution to the margins of the lagoon nearest to the sea. It seems that the modified landscape acts as an impassable barrier. Gonzaga and Pacheco (1990) described the species; they pointed as its northern and western limits, $22^{\circ} 50^{\prime} \mathrm{S}$ (Cabo Frio) and $42^{\circ} 40^{\prime} \mathrm{W}$ (Jaconé), respectively. The longitude recorded by us represents a western distribution limit at least $3.5 \mathrm{~km}$ shorter than that formerly described. The reason for that is probably related to the fragmentation and destruction of the habitat. The Restinga Antwren occupies areas which seem naturally fragmented such as patches of vegetation included in a mosaic of habitats. When stating that the bird is threatened by fragmentation this is actually related to urbanization and the consequent degradation of these natural areas.

\subsection{Threats to conservation}

The presence of the Restinga Antwren, a highly restricted and threatened species, includes this region among the priority areas for bird conservation in the Atlantic forest (Bencke et al., 2006). Nevertheless, we stress that in addition to this species, the region keeps an important biodiversity, but up to now very little is known about the ecological interactions and the exact functions developed in relation to the environmental health by most of the restricted-range plants and animals in the region. The Cabo Frio region is also indicated as a center of plant diversity, harboring many endemic and relict species (Araújo, 1997). An endangered lizard species (Liolaemus lutzae Mertenz) still inhabits the beaches of the region (CFD. Rocha, pers. comm.), and was recorded by us during the present study. Among other bird species found in the local restingas, the Black-backed Tanager Tangara peruviana (Dermarest) is considered globally vulnerable (IUCN, 2004) and occupies the region in the winter, and the Tropical Mockingbird Mimus gilvus (Vieillot), whose subspecies Mimus gilvus antelius is exclusive to restingas in the state of Rio de Janeiro 
(Rocha et al., 2005), is regionally endangered (Alves et al., 2000).

Human population growth: occupying a highly restrict range; the increasing appreciation of real estates in the region along the last decades has been aggravating the Restinga Antwren situation. Due to its proximity to the metropolitan region of Rio de Janeiro and the notorious scenic beauty of its beaches, the Restinga Antwren's region faces a high density and growth rate of human population, lacking sustainable tourism politics (during holidays and the holiday season, human population may triplicate). Consequently, the restinga habitat has been suffering an accelerated process of fragmentation, as a result of the evident conflict between the human development and the conservation of the restinga remnants. There was a highly negative effect on the restinga habitat in the district of Praia Seca (Araruama) and in the municipality of Arraial do Cabo, especially after 1998, when asphalt was laid on the state road (RJ 102) crossing the main part of the Massambaba restinga.

Lack of effective protection areas: in 1986, the same decree creating the Massambaba Environmental Protection Area (Área de Proteção Ambiental - APA) ordered the creation, within its range, of two State Reserves (Jacarepiá Reserve, in Saquarema, and Massambaba Reserve, in Arraial do Cabo). Although such reserves, which would expropriate the private areas it comprises, have not been implemented, their range is nearly entirely categorized by the APA's management plane as a Wildlife Preservation Zone (ZPVS), the most restrictive zone categorization.

Despite the creation of the management board of the APA Massambaba, in 2005, vigilance is not suitable and therefore the protection is not effective. Additionally, the region lacks governmental policies by the state and the respective municipalities, in order to restrict the soil use and to prevent illegal housing estates on protected zones. Most of these problems are concentrated in Arraial do Cabo, but this municipality includes the Ilha de Cabo Frio, an island keeping over 300 ha of suitable habitat for the Restinga Antwren, under effective control by the Brazilian Navy. Although this species was chosen as "flag-species" for the APA Massambaba in 2005, it is usually not known by policy makers and the local and state community in general. An elaborated strategy publicizing the restricted range and the critical status of the species surely can help planning measures to mitigate the impacts towards the conservation of the Restinga Antwren and its habitat.

Regarding the conservation of the area represented by our new records for the Restinga Antwren, two local decrees were created in 1990, establishing two municipal Environmental Protection Areas (APA): APA das Andorinhas and APA do Morro do Governo, both at Iguaba Grande. The latter was also included, three months later, in the Environmental Protection Area of Sapiatiba (APA Sapiatiba), by a decree of the state. Despite that, no effective action has been implemented so far, and the reasonable maintenance of the coverage in the Morro do Governo can be attributed to its management by a public federal university (Universidade Federal Fluminense).

\subsection{Recommendations}

The general possible actions to protect the Restinga Antwren might include mainly restraining the realestate planning and uncontrolled tourism; restoring of the natural areas and implementing effective protected areas. Some areas seem rather important for the conservation of this species such as Massambaba. As in other studies (Collar et al.,1992, Tobias and Willians, 1996), we indicate this area of restinga as a key area for the Restinga Antwren. The long-term existence of viable populations seems dependent on the preservation of long patches of restinga remnants in this region. Within this range, we emphasize as particularly relevant the strip of approximately $10 \mathrm{~km}$ of restinga (longitudes $42^{\circ} 11^{\prime} \mathrm{W}$ to $42^{\circ} 17 \mathrm{~W}$ ) in the area formerly designated to be the Massambaba State Reserve, in the municipality of Arraial do Cabo (site 7 in the Figure 1). That area is apparently the largest continuous extension of suitable habitat for the species.

The effective conservation of the Massambaba region is urgent and imperative to protect the Restinga Antwren, and a possible way to achieve that is encouraging the creation of private reserves. Although Rio de Janeiro is the first Brazilian state in number of Natural Heritage Private Reserves (RPPNs), presently there is none in the range known for the Restinga Antwren.

Considering the low capacity of the Atnwren family (Thamnophilidae) for moving across large open areas, we believe this species' population has already had natural disjunctions, but those have been intensely increased by human disturbances. Studies on territory size and population abundance of the Restinga Antwren, as well as the effect of the habitat fragmentation on these parameters, should help subsidize conservation measures. Despite the apparent absence of the species far from the margin of Araruama lagoon, we recommend further studies including evaluation on adjacent inland areas to confirm the presumed absence of the species. An additional interesting question would be a better investigation on a larger scale, to confirm if there is in fact a gap of $80 \mathrm{~km}$ comprised between the range of the Restinga Antwren and that of the subspecies Formicivora serrana interposita (Gonzaga and Pacheco, 1990), a very similar taxon.

Acknowledgements - We thank Associação Mico-LeãoDourado/CEPF for supporting a bird inventory (PFI 011/2003) at Iguaba Grande, allowing the start of the present study. The Universidade Federal Fluminense for the permit to use its area (NEIG). Oscar Machado, Walace L. Castro, Luiz Freire and Nilma Accioli for their support with mist-netting. Movimento Ambiental Pingo D'Água (M.A.P.A) and Instituto Biomas for the assistance and logistical support. Davor Vrcibradic for reviewing the English. Part of the data about the environmental problems in the study area was gathered in a report made by the NGO M.A.P.A for the SAVE Brasil/BirdLife International. Ministry of Education (CAPES) provided a doctor fellowship to M.B.Vecchi, 
and the Conselho Nacional de Desenvolvimento Científico e Tecnológico $(\mathrm{CNPq})$ provided a research grant to M.A.S. Alves (n. 302718/2003-6).

\section{References}

ALVES, MAS., PACHECO, JF., GONZAGA, LAP., CAVALCANTI, RB., RAPOSO, MA., YAMASHITA, C., MACIEL, NC. and CASTANHEIRA, M., 2000. Aves. In BERGALLO, HG., ROCHA, CFD., ALVES, MAS. and VanSLUYS, M., (orgs.). A fauna ameaçada de extinção do Estado do Rio de Janeiro. Rio de Janeiro: EdUERJ.

ARAÚJO, DSD., 1997. Cabo Frio Region. In DAVIS, SD., HEYWOOD, VW., HERRERA-MacBRYDE, O., VILLALOBOS, J. and HAMILTON, AC. (eds.). Centres of Plant Diversity: a guide and strategy for their conservation. The Americas. Cambrigde: WWF/IUCN, vol. 3.

BENCKE, GA., MAURÍCIO, GN., DEVELEY, PF. and GOERCK, J. (orgs.), 2006. Áreas Importantes para a Conservação das Aves no Brasil. Parte 1- Estados do domínio da Mata Atlântica. São Paulo: SAVE Brasil. 494 p.

COLLAR, NJ., GONZAGA, LP., KRABBE, N., MADROÑO NIETO, A., NARANJO, LG., PARKER, TA. and WEGE, DC., 1992. Threatened birds of the Americas: the ICBP/IUCN red data book. International Council for Bird Preservation, Cambridge.

GONZAGA, LP, and PACHECO, LF., 1990. Two new subspecies of Formicivora serrana (Hellmayr) from southeastern Brazil, and notes of type locality of Formicivora deluzae Ménétries. Bull. B. O. C., vol. 110, no. 4, p.187-193.

IUCN, 2004, 2004 IUCN Red List of Threatened Species. Available from: http://www.iucnredlist.org. Accessed on: 23 march 2006.

JOHNSON, RR., BROWN, BT., HAIGHT, LT. and SIMPSON, JM., 1981. Playback recording as a special avian censusing technique. Stud. Avian Biol., no. 6, p. 68-75.

RIDGELY, R, and TUDOR, G., 1994. Birds of South America. vol. 2. The Suboscine Passerines. Austin: University of Texas Press. 814 p.

ROCHA, CFD., Van-SLUYS, M., BERGALLO, HG. and ALVES, MAS., 2005. Endemic and threatened tetrapods in the restingas of the biodiversity corridors of Serra do Mar and of the Central da Mata Atlântica in eastern Brazil. Braz. J. Biol. $=$ Rev. Bras. Biol., vol. 65, no. 1, p. 159-168.

TOBIAS, JA., and WILLIANS, RSR., 1996. Threatened Formicivora antwrens of Rio de Janeiro state, Brazil. Cotinga, no. 5 , p. 62-66. 